\title{
Increased Litter Greatly Enhancing Soil Respiration in Betula platyphylla Forests of Permafrost Region, Northeast China
}

\author{
Hong Wei ${ }^{1,2}$ and Xiuling Man ${ }^{1,2, *}$ \\ 1 School of Forestry, Northeast Forestry University, Harbin 150040, China; weihong@nefu.edu.cn \\ 2 Key Laboratory of Sustainable Forest Ecosystem Management-Ministry of Education, Northeast Forestry \\ University, Harbin 150040, China \\ * Correspondence: xiuling.man@nefu.edu.cn; Tel.: +86-131-9953-9729
}

check for updates

Citation: Wei, H.; Man, X. Increased Litter Greatly Enhancing Soil Respiration in Betula platyphylla

Forests of Permafrost Region,

Northeast China. Forests 2021, 12, 89. https://doi.org/10.3390/f12010089

Received: 1 December 2020

Accepted: 11 January 2021

Published: 15 January 2021

Publisher's Note: MDPI stays neutral with regard to jurisdictional claims in published maps and institutional affiliations.

Copyright: (c) 2021 by the authors. Licensee MDPI, Basel, Switzerland. This article is an open access article distributed under the terms and conditions of the Creative Commons Attribution (CC BY) license (https:// creativecommons.org/licenses/by/ $4.0 /)$.

\begin{abstract}
The change of litter input can affect soil respiration (Rs) by influencing the availability of soil organic carbon and nutrients, regulating soil microenvironments, thus resulting in a profound influence on soil carbon cycle of the forest ecosystem. We conducted an aboveground litterfall manipulation experiment in different-aged Betula platyphylla forests (25-, 40- and 61-year-old) of the permafrost region, located in the northeast of China, during May to October in 2018, with each stand treated with doubling litter (litter addition, DL), litter exclusion (no-litter, NL) and control litter (CK). Our results indicated that Rs decreased under NL treatment compared with CK treatment. The effect size lessened with the increase in the stand age; the greatest reduction was found for young Betula platyphylla forest $(24.46 \%$ for 25 -year-old stand) and tended to stabilize with the growth of forest with the reduction of $15.65 \%$ and $15.23 \%$ for 40 -and 61 - year-old stands, respectively. Meanwhile, under DL treatment, Rs increased by $27.38 \%, 23.83 \%$ and $23.58 \%$ on $25-$, 40 - and 61 -year-old stands, respectively. Our results also showed that the increase caused by DL treatment was larger than the reduction caused by NL treatment, leading to a priming effect, especially on 40 - and 61-year-old stands. The change in litter input was the principal factor affecting the change of Rs under litter manipulation. The soil temperature was also a main factor affecting the contribution rate of litter to Rs of differentaged stands, which had a significant positive exponential correlation with Rs. This suggests that there is a significant relationship between litter and Rs, which consequently influences the soil carbon cycle in Betula platyphylla forests of the permafrost region, Northeast China. Our finding indicated the increased litter enhanced the Rs in Betula platyphylla forest, which may consequently increase the carbon emission in a warming climate in the future. It is of great importance for future forest management in the permafrost region, Northeast China.
\end{abstract}

Keywords: soil respiration; stand age; Betula platyphylla; litter manipulation; permafrost region

\section{Introduction}

Soil respiration (Rs) is a key process of biochemical activity in soil, during which carbon dioxide is produced as a result of metabolism of free-living soil microorganisms and of roots or root-associated microorganisms [1-3]. Total Rs is the sum of all $\mathrm{CO}_{2}$ effluxes originating from litter, soil organic matter and roots [4,5]. Rs is the main way for carbon in the soil carbon pool to return to the atmosphere [4], which is approximately $80 \mathrm{Pg}$ each year [6]. Therefore, the fluctuations in Rs can directly affect atmospheric $\mathrm{CO}_{2}$ concentration, and consequently alter the global carbon balance [7-9]. It has been reported that approximately $50 \%$ of the global belowground organic carbon is stored in soil of the cold temperate zone [10,11]. The carbon emission mainly results from Rs in this region [12], which has been significantly accelerated in the past several decades due to the global warming and human activities. Therefore, determining the responses of Rs to such a disturbance in the cold temperate zone is crucial for an accurate evaluation of carbon balance and climate-carbon feedbacks. 
Under climate change and human activity scenarios, the input quantity of plant litter will be significantly affected, resulting in great change on Rs by regulating soil microenvironments and soil microbial activities $[6,13]$. The $C$, which is directly released from litter decomposition, is about $68 \mathrm{Gt}$ of $\mathrm{CO}_{2}$ every year [4], accounting for about $70 \%$ of the annual carbon flux [6]. Data from several studies suggest that litter input is greatly influenced by changes in atmospheric $\mathrm{CO}_{2}$ concentration [14,15], which in turn exerts nonlinear effects on Rs. It has also been commonly considered that litter exclusion may reduce decomposition of soil organic $C$ due to the decrease in the easily decomposable substrate for microbes. Although litter-manipulation experiments have been widely conducted to examine the potential effects of changes in plant-derived carbon input on belowground carbon cycling [16-19], studies on the responses of Rs to altered litter inputs are very limited, particularly on how the magnitude and direction of Rs responds to litter input alteration in permafrost regions [20]. In addition to litter, stand age is another affecting factor for Rs [21]. Previous research has indicated that stand age is highly related to the physiological and structural characteristics of plants [22,23], the quantity and quality of the aboveground and belowground detritus, and root activity [24,25], all of which have great influences on Rs [26]. However, the response of Rs to stand age appears to vary somewhat in different regions. Some studies suggest that Rs decreases with stand age in temperate forests, while it increases in tropical and subtropical forests $[22,23,26]$. However, the effects of stand age on Rs in the permafrost region is seldom investigated [27-29]. Answering this question is critical to accurately assess the interaction effects among climate change, carbon cycle and forest management.

The Daxing'an Mountains area is not only the southern margin of the Eurasian permafrost region [30,31], but is also the largest natural forest area in China, and has an area of 8.35 million ha with a forest coverage rate of $84.32 \%$ [32,33]. The dominant species of trees in this region are Larix gmelinii, Betula platyphylla, Populus davidiana and Pinus sylvestris var. mongolica. As a result of large-scale fire and logging, the natural secondary forests are widely distributed [34]. Betula platyphylla, as a pioneer species, is the widely distributed natural secondary forest in this region, which accounts for $41.15 \%$ and $41.59 \%$ of the total forest area and the total forest stock, respectively $[35,36]$. There are few Betula platyphylla stands older than 80 years, because old Betula platyphylla forests are generally replaced by Larix gmelinii and mixed deciduous forests as a stand successional pathway in this region $[37,38]$. In this study, an in-situ litter-manipulation experiment was performed to determine the effect of aboveground litter on Rs over different-aged Betula platyphylla forests in the permafrost region, Northeast China. Three stand age classes, namely, 25-, 40-, and 61-year-old Betula platyphylla, stands (hereafter called 25 a, 40 a and 61 a, respectively) were selected, and the Rs under litter exclusion (no-litter, NL), litter addition (litter doubling, $\mathrm{DL}$ ) and control litter (CK) were measured at monthly intervals from May to October in 2018. The objective of this study was (1) to determine the seasonal dynamics of Rs under litter manipulation and its correlated factors in different-aged stands; (2) to investigate the contribution of litter to Rs under different-aged stands; and (3) to assess the main driving factors affecting Rs under litter manipulation in different-aged Betula platyphylla forests of the permafrost region, Northeast China.

\section{Materials and Methods}

\subsection{Site Description}

The experiments were conducted at the Mohe Forest Ecosystem National Positioning Observation and Research Station $\left(53^{\circ} 28^{\prime} 02.94^{\prime \prime}\right.$ N, $122^{\circ} 20^{\prime} 16.98^{\prime \prime}$ E, 290 m a.s.L.), in Heilongjiang province, located in northeastern China. The area belongs to a cold temperate monsoon climate with a mean annual temperature of $-4.9{ }^{\circ} \mathrm{C}$. Mean annual precipitation ranges from 350 to $500 \mathrm{~mm}$, with $60 \%$ of falling in from July to August [39,40]. In this region, snowpack covers the land more than half the year (from October to April). This region has a mean annual sunshine of $2594 \mathrm{~h}$ and a frost-free period of 89 days, typically from June to September [32]. The soil type belongs to brown coniferous forest soil. The forests 
in the area have not been cut or thinned since 2014, and are in a state of natural growth. The soil physiochemical properties at $0-20 \mathrm{~cm}$ depth and other relevant information for the sampling squares are shown in Table 1.

Table 1. Characteristics of three different-aged Betula platyphylla forests of the permafrost region, Northeast China.

\begin{tabular}{cccc}
\hline Site Characteristics $(\boldsymbol{n}=\mathbf{3})$ & $\mathbf{2 5} \mathbf{~ a}$ & $\mathbf{4 0} \mathbf{~}$ & $\mathbf{6 1} \mathbf{a}$ \\
\hline Slope $\left({ }^{\circ}\right)$ & $3 \pm 1$ & $2 \pm 1$ & $6 \pm 2$ \\
Density $\left(\right.$ ind $\left.\cdot \mathrm{hm}^{-2}\right)$ & $1825 \pm 225$ & $2075 \pm 300$ & $1820 \pm 250$ \\
Canopy density & $0.7 \pm 0.1$ & $0.9 \pm 0.1$ & $0.8 \pm 0.1$ \\
Mean height $(\mathrm{m})$ & $8.6 \pm 1.6$ & $11.1 \pm 3.0$ & $15.2 \pm 3.5$ \\
DH & $7.1 \pm 1.8$ & $9.5 \pm 1.8$ & $12.4 \pm 2.2$ \\
Siameter at breast height $(\mathrm{cm})$ & $4.6 \pm 0.3$ & $28.62 \pm 0.2$ & $4.8 \pm 0.2$ \\
Soil total organic carbon content $\left(\mathrm{g}^{-\mathrm{kg}^{-1}}\right)$ & $13.35 \pm 0.61$ & $1.36 \pm 0.07$ & $55.69 \pm 1.57$ \\
\hline
\end{tabular}

Values are followed by mean $\pm \mathrm{SD}$.

\subsection{Experimental Design}

For each stand, three $20 \mathrm{~m} \times 20 \mathrm{~m}$ experimental plots were established in a randomized block design in April 2018 for the Rs under a litter manipulation experiment of different-aged Betula platyphylla forests of the permafrost region, Northeast China. Litter manipulation consisted of three treatments that were replicated three times, in each plot: litter exclusion (no-litter, NL), litter addition (litter doubling, DL) and control litter (CK) input. For NL, all litter materials on the soil surface were removed at the beginning of the study. For DL, all litter materials on the soil surface were doubled by adding litter removed from NL plots. To prevent the input of fresh fallen litter, a $1 \mathrm{~m} \times 1 \mathrm{~m}$ nylon mesh trap was placed just above the soil collar in each NL plot, approximately $0.7 \mathrm{~m}$ above the soil surface with a mesh size of $1 \mathrm{~mm}$. The litter in the trap was removed and redistributed on the DL plots at monthly intervals. The CK input was kept in the natural status of litter on the soil surface and received the normal input process of aboveground litter during the whole study period.

\subsection{Measurement of Rs, Soil Temperature, and Soil Water Content}

Rs was measured at monthly intervals from May 2018 to October 2018 using a portable, closed-chamber technique (Li-6400 Automated Soil $\mathrm{CO}_{2}$ Flux System, Li-Cor Inc., Lincoln, NE, USA) connected to a standard soil chamber (6400-09), except for the period of November-April during which soil temperature falls below $-10{ }^{\circ} \mathrm{C}$ and the Li-6400 instrument is inoperable at such low temperatures. Under each litter manipulation treatment, PVC soil collars (20 cm in diameter and $10 \mathrm{~cm}$ in height) were inserted randomly for Rs measurements, which were left in situ for the entire period. Soil collars were inserted $5 \mathrm{~cm}$ into the soil surface and allayed to equilibrate for at least $24 \mathrm{~h}$ before taking the first measurement. In order to eliminate the contribution of aboveground plants on Rs, aboveground biomass inside each collar was removed by hand at least one day before each Rs measurement. All Rs measurements were taken three times between 9:00-12:00 on each sampling date. The mean Rs in each soil collar, which was determined from three replicates of the same treatment, was used for data analysis. As Rs measurement was taken, soil temperature at $10 \mathrm{~cm}$ depth and soil water content in the top $10 \mathrm{~cm}$ adjacent to each collar were recorded simultaneously by using the Li-Cor 6400 soil temperature probe and TDR (Model TDR100, Spectrum Technologies Inc., Plainfield, IL, USA).

\subsection{Measurement of Litter Quantity and Quality}

Litter was collected from three $1 \mathrm{~m} \times 1 \mathrm{~m}$ nylon mesh traps at permanent random locations, which was approximately $0.7 \mathrm{~m}$ above the soil surface with a mesh size of $1 \mathrm{~mm}$ in each plot from May 2018 to October 2018. All the litter in the traps were collected and 
weighed on site to calculate the litter input quality after measuring the soil respiration rate at a monthly scale. The collected litter was combined on site to gain one composite sample per stand, then brought to the laboratory to be oven-dried at $65^{\circ} \mathrm{C}$ to a constant weight. The dried litter was ground and screened with a $2.5 \mathrm{~mm}$ metal sieve for measuring the total organic carbon $(\mathrm{C})$ content and total nitrogen $(\mathrm{N})$ content. The $\mathrm{C}$ content was measured by the dichromate oxidation method [41]. The $\mathrm{N}$ content was measured by the semi-micro-Kjeldahl method [42].

\subsection{Data Analysis}

We calculated the effect size of litter manipulation on Rs, compared to Rs under control litter input, using the following Equation [43]:

$$
\text { Effect size }(\%)=\left(\mathrm{R}_{\mathrm{NL}(\mathrm{DL})}-\mathrm{R}_{\mathrm{CK}}\right) / \mathrm{R}_{\mathrm{CK}} \times 100
$$

where $R_{N L}$, $R_{D L}$ and $R_{C K}$ are the mean Rs with the three litter treatments.

The relationship between Rs and soil temperature (T) or soil water content $(\mathrm{W})$ was examined using linear and nonlinear regression models [21,44]:

$$
\begin{gathered}
R s=a e^{b T} \\
R s=a+b W \\
R s=a e^{b T} W^{c}
\end{gathered}
$$

where Rs is the mean soil respiration rate $\left(\mu \mathrm{mol} \cdot \mathrm{m}^{-2} \cdot \mathrm{s}^{-1}\right), \mathrm{T}$ is the mean soil temperature $\left({ }^{\circ} \mathrm{C}\right)$ at a $10 \mathrm{~cm}$ depth, $\mathrm{W}$ is the mean soil water content $(\%)$ at a $10 \mathrm{~cm}$ depth and a, b and $\mathrm{c}$ are constants fitted to the regression equation.

$\mathrm{Q}_{10}$, the temperature sensitivity index for Rs, refers to the ratio between the value of Rs at a given temperature to its value at a temperature $10{ }^{\circ} \mathrm{C}$ lower than the given temperature. $\mathrm{Q}_{10}$ is generally expressed as follows [2,41]:

$$
\mathrm{Q}_{10}=\mathrm{e}^{10 \mathrm{~b}}
$$

where $b$ is the fitted parameter obtained from Equation (2).

A one-way ANOVA analysis followed by post hoc LSD tests were performed to determine the differences in the effect size of Rs between groups in each stand age in the whole study period. A two-way ANOVA analysis was applied to determine the effects of stand age and litter manipulation on soil respiration rate, soil temperature and soil water content. SPSS 25.0 for Windows was used to perform the analysis (IBM Corp., Armonk, NY, USA). Graphic illustrations were generated using OriginPro 2019b (OriginLab Corp., Northampton, MA, USA.) software and Matlab 2018a (MathWorks Inc., Natick, MA, USA) software. Mean values \pm standard deviation were reported in the text. Statistically significant differences were identified when $p<0.05$.

\section{Results}

\subsection{Variability of Rs under Litter Manipulation}

There were strong seasonal variations in Rs under litter manipulation (Figure 1), irrespective of what the stand age was. Rs first increased and then decreased during the whole study period. The highest Rs was found in June-August as opposed to other months during the study period for all the treatment, while the lowest Rs was shown in October for all the stand ages. Under litter manipulation, the Rs ranged from 0.39 to $6.84 \mu \mathrm{mol} \cdot \mathrm{m}^{-2} \cdot \mathrm{s}^{-1}, 0.57$ to $9.23 \mu \mathrm{mol} \cdot \mathrm{m}^{-2} \cdot \mathrm{s}^{-1}$ and 0.71 to $9.06 \mu \mathrm{mol} \cdot \mathrm{m}^{-2} \cdot \mathrm{s}^{-1}$ for $25-, 40-$ and 61-year-old stands, respectively, during the whole study period. The Rs under DL treatment was significantly higher than that under CK and NL treatment, whereas there was a significant difference in Rs observed between CK and NL treatment for all the stand ages (Table $2, p<0.01$ ). 

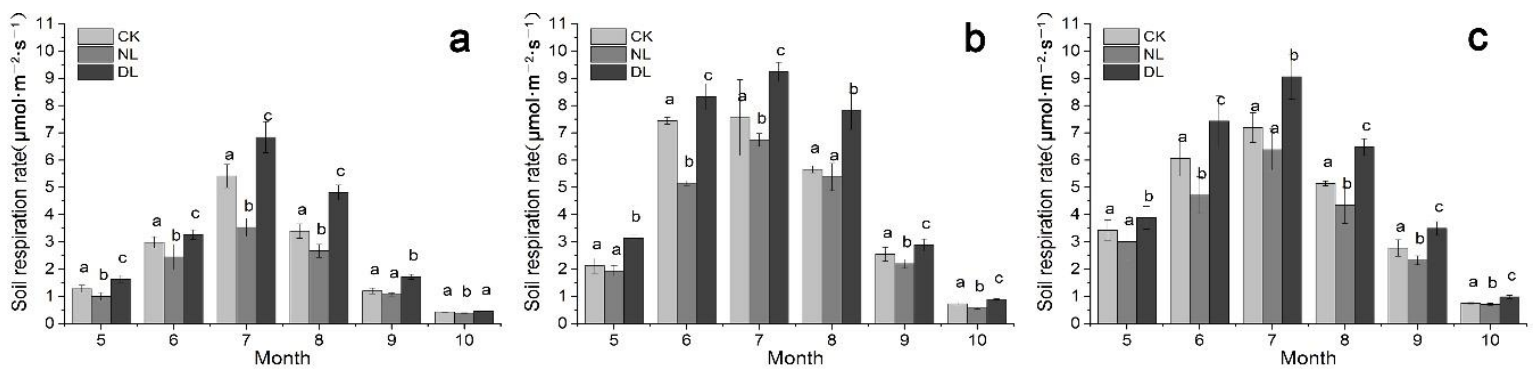

Figure 1. The monthly pattern of soil respiration rate under litter manipulation during the study period (May to October in 2018) in different-aged Betula platyphylla forests of permafrost region, Northeast China. Stand ages included 25 (a), 40 (b) and 61 (c). Litter manipulation included NL (no-litter), DL (double litter) and CK (control litter) in each stand. Error bars indicate the standard deviation $(n=9)$. Lowercase letters represent significant differences under the same month and varied litter manipulation $(p<0.05)$.

Table 2. Effects of stand age and litter manipulation on soil respiration rate (Rs), soil temperature and soil water content in different-aged Betula platyphylla forests of permafrost region, Northeast China.

\begin{tabular}{ccccccc}
\hline & \multicolumn{2}{c}{ Rs $\left(\mu \mathbf{m o l} \cdot \mathbf{m}^{-\mathbf{2}} \cdot \mathbf{s}^{-\mathbf{1}}\right)$} & \multicolumn{2}{c}{ Soil Temperature $\left({ }^{\circ} \mathbf{C}\right)$} & \multicolumn{2}{c}{ Soil Water Content $(\%)$} \\
\cline { 2 - 7 } & F & $p$ & F & $p$ & F & $p$ \\
\hline Stand age (S) & 32.275 & $<0.001$ & 8.201 & $<0.001$ & 58.016 & $<0.001$ \\
Litter manipulation (L) & 19.444 & $<0.001$ & 5.037 & 0.007 & 7.808 & $<0.001$ \\
S $\times$ L & 0.707 & 0.587 & 3.566 & 0.007 & 0.443 & 0.443 \\
\hline
\end{tabular}

\subsection{Effect Size of Rs under Litter Manipulation}

The effect size of Rs under litter manipulation during the study period was shown in Figure 2. Our results showed that Rs was increased under DL treatment, and the greatest increase was found in September (43.12\%), May (47.58\%) and October (30.67\%) for 25-, 40and 61-year-old stands, respectively. The Rs increased by an average of $27.38 \%, 23.83 \%$ and $23.58 \%$ for $25-, 40-$ and 61-year-old stands, under DL treatment throughout the study period. And Rs was reduced under NL treatment, the greatest reduction was found on July for 25-year-old stands, and June for 40- and 61-year-old stands. Under NL treatment, the range of Rs reduction was $9.30-34.81 \%, 4.86-30.68 \%$ and $5.33-22.29 \%$ for 25 -year-old stands, and June for 40- and 61-year-old stands.
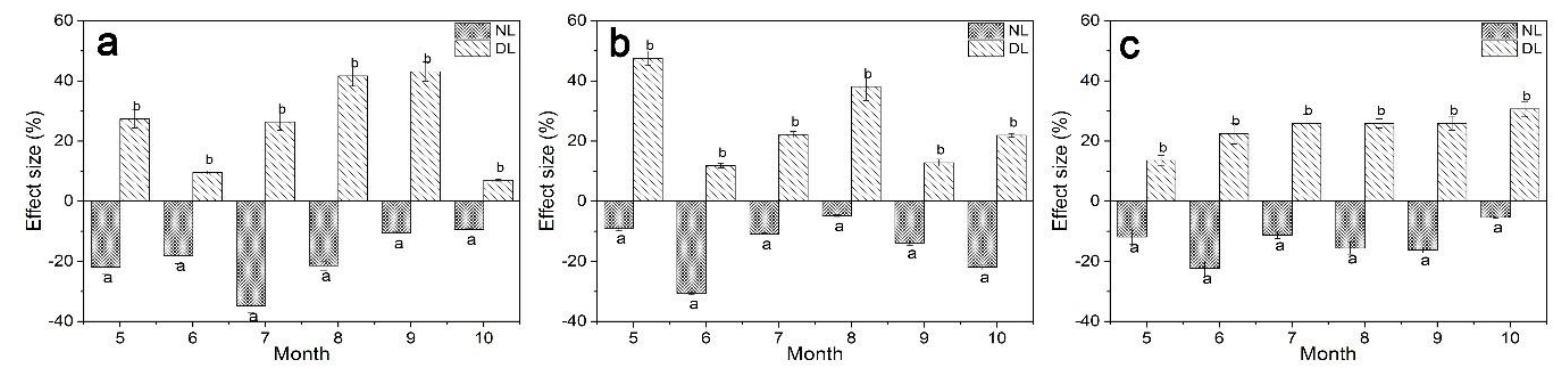

Figure 2. Effect size of NL (no-litter) and DL (double litter) treatments on soil respiration rates during the study period (May to October in 2018) in different-aged Betula platyphylla forests of the permafrost region, Northeast China. Stand ages included 25 (a), 40 (b) and 61 (c). We calculated the effect size of litter manipulation on Rs, compared to Rs under control litter input using the following equation: Effect size $(\%)=\left(R_{N L(D L)}-R_{C K}\right) / R_{C K} \times 100$, where $R_{N L}, R_{D L}$ and $R_{C K}$ are the mean $\mathrm{R}_{\mathrm{S}}$ under no-litter, double liter and control litter treatment. Error bars indicate the standard deviation $(n=9)$. Lowercase letters represent significant differences under the same month and varied litter manipulation $(p<0.05)$. 


\subsection{Soil Temperature and Soil Water Content in Relation to Rs}

Figures 3 and 4 showed the dynamic variations in the soil temperature and soil water content of different-aged Betula platyphylla forests during the study period. Our results indicated that there was a significant positive exponential correlation between soil temperature (at $10 \mathrm{~cm}$ depth) and Rs under litter manipulation, irrespective of stand age (Figure $5 \mathrm{a}-\mathrm{c}$ ). The result of the exponential models showed that the monthly variation of the Rs could be explained by the soil temperature (at $10 \mathrm{~cm}$ depth), with $\mathrm{R}^{2}$ values ranging from 0.684 to $0.810,0.550$ to 0.622 and 0.321 to 0.450 under litter manipulation, for 25-, 40- and 61-year-old stands, respectively. Soil water content also showed a positive linear correlation, with Rs under litter manipulation, irrespective of stand age, except those on 25-year-old stands under NL and DL treatment, which showed negative linear correlation with Rs (Figure 5d). While, the relationship between Rs and soil water content was significant only on 40-year-old stands under CK and NL treatment (Figure 5e, $p<0.01$ ).

Considering the combined effects of soil temperature and soil water content on Rs, multiple regressions were established. Based on our analysis, Rs was better fitted with combined factors of soil temperature and soil water contents, than with soil temperature or soil water contents alone, with $\mathrm{R}^{2}$ values of $0.842-0.896,0.689-0.758$ and $0.592-0.716$ for 25-, 40- and 61-year-old stands, respectively (Figure 6).

Calculation of the temperature sensitivity $\left(\mathrm{Q}_{10}\right)$ at the monthly scale based on the soil temperature (at $10 \mathrm{~cm}$ depth) showed that the $\mathrm{Q}_{10}$ values were 8.25, 3.39 and 2.32 in 25-, 40and 61-year-old stands under CK treatment (Table 3). Both NL and DL treatment increased the $\mathrm{Q}_{10}$ values on 40 -year-old stands, while the $\mathrm{Q}_{10}$ values decreased under NL treatment and increased under DL treatment (5.99 and 10.70, respectively) on 25-year-old stands, which was contrary to the study on 61-year-old stands (2.64 and 2.29 under NL and DL treatment, respectively).
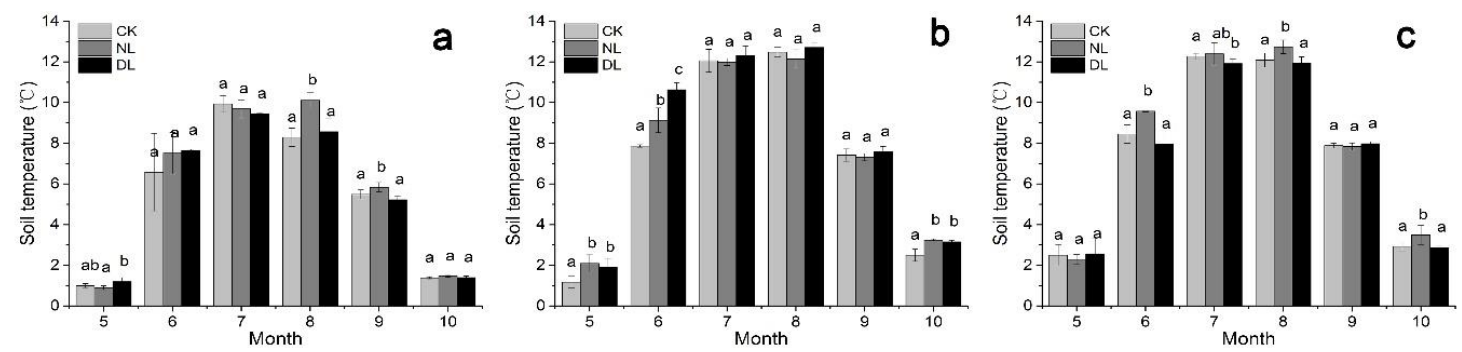

Figure 3. The monthly pattern of soil temperature (at $10 \mathrm{~cm}$ depth) under litter manipulation during the study period (May to October in 2018) in different-aged Betula platyphylla forests of the permafrost region, Northeast China. Stand ages included 25 (a), 40 (b) and 61 (c). Litter manipulation included NL (no-litter), DL (double litter) and CK (control litter) in each stand. Error bars indicate the standard deviation $(n=9)$. Lowercase letters represent significant differences under the same month and varied litter manipulation $(p<0.05)$.
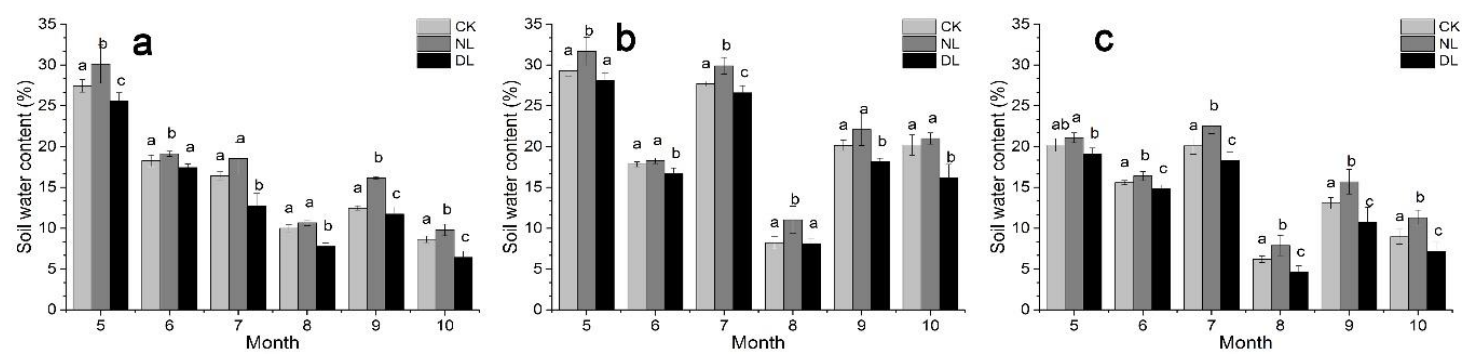

Figure 4. The monthly pattern of soil water content (at $10 \mathrm{~cm}$ depth) under litter manipulation during the study period (May to October in 2018) in different-aged Betula platyphylla forests of the permafrost region, Northeast China. Stand ages included 25 (a), 40 (b) and 61 (c). Litter manipulation included NL (no-litter), DL (double litter) and CK (control litter) in each stand. Lowercase letters represent significant differences under the same month and varied litter manipulation $(p<0.05)$. Error bars indicate the standard deviation $(n=9)$. 

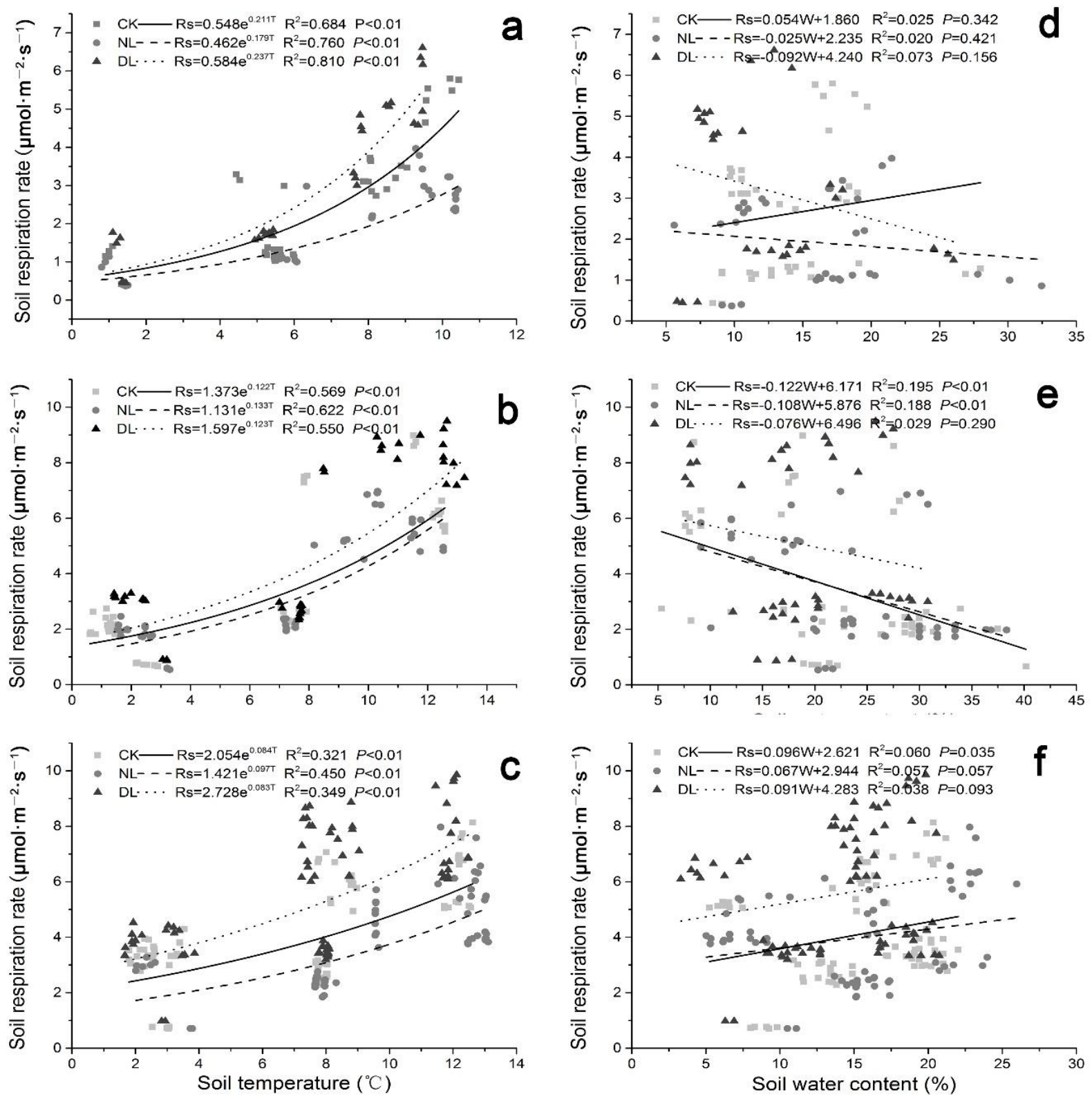

Figure 5. Fitted models of the soil respiration rate under litter manipulation against the soil temperature (at $10 \mathrm{~cm}$, left) and the soil water content (at $10 \mathrm{~cm}$, right) in different-aged Betula platyphylla forests of permafrost region, Northeast China. Stand ages included $25(\mathbf{a}, \mathbf{d}), 40(\mathbf{b}, \mathbf{e})$ and $61(\mathbf{c}, \mathbf{f})$. Litter manipulation for each stand included NL (no-litter), DL (double litter) and CK (control litter).

Table 3. The temperature sensitivity parameter $\mathrm{Q}_{10}$ in different-aged Betula platyphylla forests of the permafrost region, Northeast China. Stand ages included 25 (a), 40 (b) and 61 (c). Litter manipulation for each stand included NL (no-litter), DL (double litter) and CK (control litter).

\begin{tabular}{ccccccccccc}
\hline & & 25 & & & & $\mathbf{4 0}$ & & & $\mathbf{6 1} \mathbf{a}$ & \\
\hline \multirow{2}{*}{$\mathrm{Q}_{10}$} & $\mathrm{CK}$ & $\mathrm{NL}$ & $\mathrm{DL}$ & $\mathrm{CK}$ & $\mathrm{NL}$ & $\mathrm{DL}$ & $\mathrm{CK}$ & $\mathrm{NL}$ & $\mathrm{DL}$ \\
& 8.25 & 5.99 & 10.70 & 3.39 & 3.78 & 3.42 & 2.32 & 2.64 & 2.29 \\
\hline
\end{tabular}




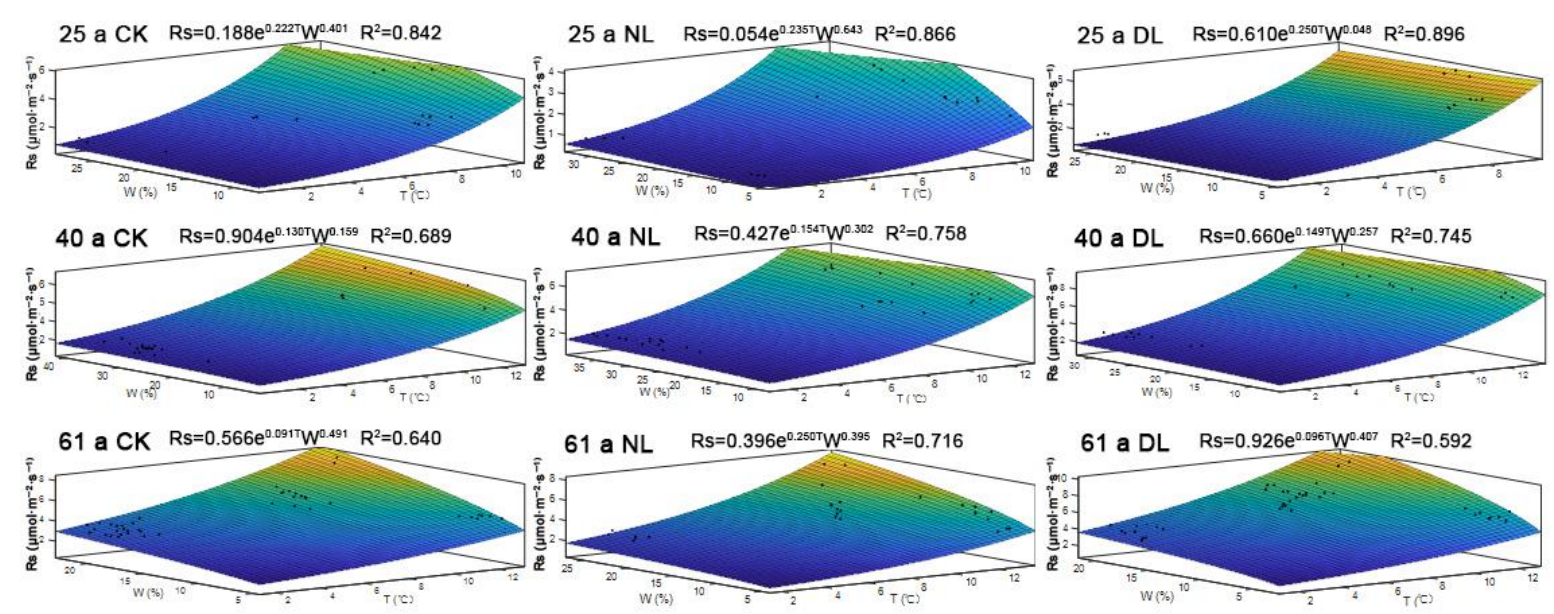

Figure 6. The best-fit models based on the soil temperature $(\mathrm{T})$ and the soil water content $(\mathrm{W})$ for the monthly soil respiration (Rs) rate under litter manipulation of the different-aged Betula platyphylla forests of the permafrost region, Northeast China. Stand ages included 25, 40 and 61. Litter manipulation for each stand included NL (no-litter), DL (double litter) and CK (control litter).

\subsection{Litter Quality and Quantity in Relation to Rs}

Our results showed that the inputs of litter quantity in Betula platyphylla forests of the permafrost region, Northeast China, were mainly concentrated in August and September, irrespective of stand age, which was much higher than other months (Figure 7). During the study period, the total litter input of 25-year-old stands $\left(1.01 \mathrm{t} / \mathrm{hm}^{2}\right)$ was significantly lower than those of 41- and 60-year-old stands ( 2.38 and $2.13 \mathrm{t} / \mathrm{hm}^{2}$, respectively). Our results also found that the total organic carbon content of litter decreased with the increase of stand age (Table A1). The average carbon content of litter was $494.83 \pm 14.62,483.12 \pm 17.08$ and $426.42 \pm 13.42 \mathrm{~g} / \mathrm{kg}$ for 25-, 40 - and 61-year-old stands, respectively. While, the $\mathrm{N}$ content of litter followed the order of: $25 \mathrm{a}(13.57 \pm 0.14 \mathrm{~g} / \mathrm{kg})>61 \mathrm{a}(12.07 \pm 0.65 \mathrm{~g} / \mathrm{kg})>40 \mathrm{a}$ $(11.35 \pm 0.55 \mathrm{~g} / \mathrm{kg})$, which resulted in a higher C:N in 40-year-old stand $(42.57 \pm 1.50)$ than $25-(36.62 \pm 1.08)$ and 61-year-old stands (35.34 \pm 1.11$)$.

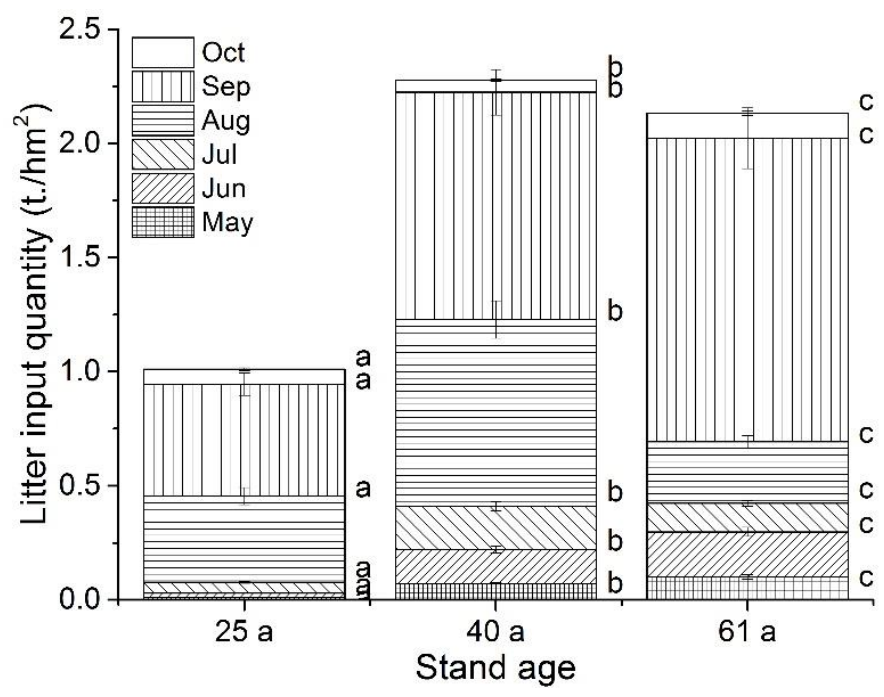

Figure 7. The litter input quantity during the study period (May to October 2018) in differentaged Betula platyphylla forests of permafrost region, Northeast China. Lowercase letters ( $a, b$ and $c)$ represent significant differences under the same month and varied stand age $(p<0.05)$. Error bars indicate the standard deviation $(n=9)$. 
Pearson correlation analysis showed that there was a significant negative exponential correlation between Rs and litter input one month ago; r was $0.783^{* *}, 0.808^{* *}$ and $0.815^{* *}$ for 25-, 40- and 61-year-old stands, respectively. No significant correlation was observed between Rs and litter quantity $(p>0.05)$. The regression equations are shown in Table A2.

\section{Discussion}

Our results indicated that both litter manipulation and stand age had significant influence on Rs of Betula platyphylla forests in the permafrost region, Northeast China. Rs was significantly increased under DL treatment, compared with CK treatment, irrespective of stand age. This finding was in accordance with the results of other studies, which had shown that additional litter provided easily-decomposable substrate to microbes, thus increasing soil organic $C$ mineralization and microbial respiration $[11,17]$, then leading to the increase of Rs. Besides, the significantly lower soil water content under DL treatment of 25- and 40-year-old stands (Figure $4, p<0.05$ ) could also partly explain the higher Rs under DL treatment, because of the negative linear correlation between them (Figure 5). On 40-year-old stand, the significantly higher soil temperature under DL treatment (Figure 3, $p<0.05$ ), which had a positive exponential correlation with Rs (Figure 5), was accountable for the increase in Rs [42]. Conversely to DL treatment, we found a decline in Rs under NL treatment, which was consisted with the results in other regions $[6,13,16,43-45]$. The withdrawal of fresh substrate and the great increase in soil water content were believed to be the reasons for reducing Rs under NL treatment $[4,7,17,46]$. Additionally, NL could have strong effects on the movement of DOC (dissolved organic carbon) from the litter layer to the soil $[18,46]$, leading to decreased soil microbial biomass or activity, and thereby decreasing Rs.

In the study, we found that increase in Rs induced by DL treatment were $27.38 \%$, $23.83 \%$ and $23.58 \%$ for $25-, 40-$ and $61-y e a r-o l d ~ s t a n d s$, respectively. The average reduction of Rs under NL treatment was $24.26 \%, 15.65 \%$ and $15.23 \%$ for $25-$, 40 - and 61-year-old stands, respectively. The effect size of Rs under litter manipulation on the permafrost region was still lower than those of other regions [42]. This could be interpreted by the greater $\mathrm{C} / \mathrm{N}$ ratio of litter in this region (Table $\mathrm{A} 1$ ), which had been reported to degrade easily under a $\mathrm{C} / \mathrm{N}$ ratio of $<25$ [47]. Besides, the lower soil temperature and poor litter quality of permafrost region (1.01-2.28 t/ $\left.\mathrm{hm}^{2}\right)$ inhibited the microbial activity, decreased the richness and diversity of microbial species and then reduced the decomposition rate of litter, and finally resulted in a lower effect size than those in other regions [46,47]. The reduction of Rs under NL treatment in 25-year-old stands (24.26\%) was higher than those in $40-(15.65 \%)$ and 61-year-old stands (15.23\%), which concurred with the studies of other regions $[43,47]$. It can be explained by the lower SOC and TN content of soil (Table 1), and the lesser litter input (Figure 7), which resulted in lower heterotrophic respiration, leading to greater reduction under NL treatment in 25-year-old stands [35,48]. Besides, the lower soil temperature of 25-year-old stands (Figure 3) could also partly explain the greater reduction. Lower temperature decreased microbial activity, decreased the richness and diversity of microbial species, and finally lead to a lower heterotrophic respiration, resulting in a higher reduction of Rs under NL [21,43]. With the increase of stand age, the effect size of Rs under NL treatment first decreased to the middle-aged forest, and then remained stable with the continuous growth of the Betula platyphylla forest. Great variability in Rs under NL treatment in young stands also implied that the effect of reduced litter input on soil respiration would lessen with the growth of the Batula platyphylla forest in the permafrost region, Northeast China $[43,49]$.

The increase in Rs induced by DL treatment $(27.38 \%, 23.83 \%$ and $23.58 \%$ for $25-$, 40- and 61-year-old stands, respectively) outpaced the decrease in NL treatment (24.46\%, $15.65 \%$ and $15.23 \%$ for $25-$, $40-$ and 61 -year-old stand, respectively), especially on $40-$ and 61-year-old stands, which meant the increased losses of $\mathrm{CO}_{2}$ from soils cannot be attributed to litter $C$ addition alone [46,50,51]. Some studies indicated that the amount of labile $C$ inputs increased under DL treatment, which could contribute to the soil organic 
$C$ mineralization, resulting in a priming effect $[52,53]$. Our results provided evidence for priming effects that did occur under DL treatment in Betula platyphylla forests of the permafrost region, especially in 40- and 61-year-old stands. The greater priming effect size could be partly explained by the quantity of the litterfall. The total litterfall was relatively greater in 41- $\left(2.28 \mathrm{t} / \mathrm{hm}^{2}\right)$ and 61-year-old stands $\left(2.13 \mathrm{t} / \mathrm{hm}^{2}\right)$ than in 25-year-old stands $\left(1.01 \mathrm{t} / \mathrm{hm}^{2}\right)$ (Figure 7). The increase of easily-decomposable substrate to microbes resulted in a higher microbial decomposition activity, resulting in a higher priming effect of 40 - and 61-year-old stands.

In the present study, we did not determine soil properties and the separate components of Rs, and therefore cannot quantify their contribution, but this may be one reason for the differences in Rs in forests with litter manipulation. Thus, we propose that future studies focus on how the components of Rs and soil properties respond to litter manipulation with the consideration of stand ages in the permafrost region, Northeast China.

\section{Conclusions}

The study enhanced our understanding of how litter manipulation affects Rs in different-aged Betula platyphylla forests of the permafrost region, Northeast China. Through the field litter manipulation experiment, we found that litter manipulation had a great influence on the Rs of Betula platyphylla forests. Our results showed that litter exclusion decreased Rs, which was possibly due to the withdrawal of fresh substrate. The greatest reduction of Rs under NL treatment was found on 25-year-old stands, which might be linked to the soil temperature and the quality of soil $C$ pools. The effect of reduced litter input on soil respiration lessened with the increasing age of Betula platyphylla forest in the permafrost region, Northeast China. The larger priming effect size under DL on Rs was found on 40- and 61-year-old stands, which was much higher than the reduction caused by NL treatment. The effect of double litter input on soil C release tended to stabilize along with stand maturation, as evidenced by the priming effect size in the 40- and 61-year-old Betula platyphylla forests. Future climate warming will lead to an increase in litter, which inevitably will enhance Rs in Betula platyphylla forests of the permafrost region, Northeast China. Such results are of great importance in accessing the carbon cycle and formulating forest management strategies in the permafrost region of northeast China.

Author Contributions: Conceptualization, X.M. and H.W.; methodology, X.M. and H.W.; software, H.W.; validation, X.M.; investigation, H.W.; resources, X.M.; data curation, H.W.; writing-original draft preparation, H.W.; writing-review and editing, H.W.; funding acquisition, X.M. All authors have read and agreed to the published version of the manuscript.

Funding: This research was funded by National Natural Science Foundation of China, grant number 31770488.

Institutional Review Board Statement: Not applicable.

Informed Consent Statement: Not applicable.

Data Availability Statement: Data sharing not applicable.

Acknowledgments: We thank the staff who provided assistance for sampling and investigations from Mohe Forest Ecosystem National Positioning Observation and Research Station.

Conflicts of Interest: The authors declare no conflict of interest.

\section{Appendix A}


Table A1. Chemical properties of the litter in Betula platuphylla forests of the permafrost region, Northeast China.

\begin{tabular}{|c|c|c|c|c|c|c|c|c|c|}
\hline & \multicolumn{3}{|c|}{25 a } & \multicolumn{3}{|c|}{40 a } & \multicolumn{3}{|c|}{$61 a$} \\
\hline & $C(g / k g)$ & $N(g / k g)$ & $C: N$ & $C(\mathrm{~g} / \mathrm{kg})$ & $\mathrm{N}(\mathrm{g} / \mathrm{kg})$ & $\mathrm{C}: \mathrm{N}$ & $C(\mathrm{~g} / \mathrm{kg})$ & N(g/kg) & $C: N$ \\
\hline 5 & $\begin{array}{c}512.39 \pm \\
15.14 \mathrm{a}\end{array}$ & $\begin{array}{c}13.99 \pm \\
0.20 \mathrm{a}\end{array}$ & $\begin{array}{c}36.63 \pm \\
1.02 \mathrm{a}\end{array}$ & $\begin{array}{c}500.27 \pm \\
17.69 \mathrm{a}\end{array}$ & $\begin{array}{c}11.70 \pm \\
0.57 \mathrm{~b}\end{array}$ & $\begin{array}{c}42.76 \pm \\
1.39 \mathrm{~b}\end{array}$ & $\begin{array}{c}438.45 \pm \\
13.90 \mathrm{~b}\end{array}$ & $\begin{array}{c}12.47 \pm \\
0.67 \mathrm{c}\end{array}$ & $\begin{array}{c}35.17 \pm \\
1.08 \mathrm{a}\end{array}$ \\
\hline 6 & $\begin{array}{c}457.12 \pm \\
13.51 \mathrm{a}\end{array}$ & $\begin{array}{c}12.45 \pm \\
0.14 \mathrm{a}\end{array}$ & $\begin{array}{c}36.73 \pm \\
1.03 \mathrm{a}\end{array}$ & $\begin{array}{c}446.30 \pm \\
15.78 \mathrm{a}\end{array}$ & $\begin{array}{c}10.41 \pm \\
0.50 \mathrm{~b}\end{array}$ & $\begin{array}{c}42.87 \pm \\
1.41 \mathrm{~b}\end{array}$ & $\begin{array}{c}391.15 \pm \\
12.40 \mathrm{~b}\end{array}$ & $\begin{array}{c}11.09 \pm \\
0.60 \mathrm{c}\end{array}$ & $\begin{array}{c}35.26 \pm \\
1.15 \mathrm{a}\end{array}$ \\
\hline 7 & $\begin{array}{c}494.83 \pm \\
14.62 \mathrm{a}\end{array}$ & $\begin{array}{c}13.57 \pm \\
0.16 \mathrm{a}\end{array}$ & $\begin{array}{c}36.46 \pm \\
1.03 \mathrm{a}\end{array}$ & $\begin{array}{c}483.12 \pm \\
17.08 \mathrm{a}\end{array}$ & $\begin{array}{c}11.35 \pm \\
0.61 \mathrm{~b}\end{array}$ & $\begin{array}{c}42.57 \pm \\
1.50 \mathrm{~b}\end{array}$ & $\begin{array}{c}423.42 \pm \\
13.42 \mathrm{~b}\end{array}$ & $\begin{array}{c}12.09 \pm \\
0.65 \mathrm{c}\end{array}$ & $\begin{array}{c}35.01 \pm \\
1.08 \mathrm{a}\end{array}$ \\
\hline 8 & $\begin{array}{c}482.96 \pm \\
14.27 \mathrm{a}\end{array}$ & $\begin{array}{c}13.52 \pm \\
0.16 \mathrm{a}\end{array}$ & $\begin{array}{c}35.72 \pm \\
1.10 \mathrm{a}\end{array}$ & $\begin{array}{c}471.53 \pm \\
16.67 \mathrm{a}\end{array}$ & $\begin{array}{c}11.31 \pm \\
0.73 \mathrm{~b}\end{array}$ & $\begin{array}{c}41.70 \pm \\
1.58 \mathrm{~b}\end{array}$ & $\begin{array}{c}413.26 \pm \\
13.10 \mathrm{~b}\end{array}$ & $\begin{array}{c}12.05 \pm \\
0.64 \mathrm{c}\end{array}$ & $\begin{array}{c}34.30 \pm \\
0.99 \mathrm{a}\end{array}$ \\
\hline 9 & $\begin{array}{c}472.89 \pm \\
13.97 \mathrm{a}\end{array}$ & $\begin{array}{c}13.29 \pm \\
0.15 \mathrm{a}\end{array}$ & $\begin{array}{c}35.59 \pm \\
1.11 \mathrm{a}\end{array}$ & $\begin{array}{c}461.70 \pm \\
16.32 \mathrm{a}\end{array}$ & $\begin{array}{c}11.11 \pm \\
0.50 \mathrm{~b}\end{array}$ & $\begin{array}{c}41.55 \pm \\
1.63 \mathrm{~b}\end{array}$ & $\begin{array}{c}404.64 \pm \\
12.82 \mathrm{~b}\end{array}$ & $\begin{array}{c}11.84 \pm \\
0.64 \mathrm{c}\end{array}$ & $\begin{array}{c}34.18 \pm \\
0.98 \mathrm{a}\end{array}$ \\
\hline 10 & $\begin{array}{c}537.63 \pm \\
15.88 \mathrm{a}\end{array}$ & $\begin{array}{c}15.36 \pm \\
0.21 \mathrm{a}\end{array}$ & $\begin{array}{c}35.00 \pm \\
1.02 \mathrm{a}\end{array}$ & $\begin{array}{c}524.90 \pm \\
18.56 \mathrm{a}\end{array}$ & $\begin{array}{c}12.85 \pm \\
0.82 \mathrm{~b}\end{array}$ & $\begin{array}{c}40.86 \pm \\
1.44 \mathrm{~b}\end{array}$ & $\begin{array}{c}460.04 \pm \\
14.58 \mathrm{~b}\end{array}$ & $\begin{array}{c}13.69 \pm \\
0.74 \mathrm{c}\end{array}$ & $\begin{array}{c}33.61 \pm \\
1.01 \mathrm{a}\end{array}$ \\
\hline Average & $\begin{array}{c}492.97 \pm \\
14.57 \mathrm{a}\end{array}$ & $\begin{array}{c}13.70 \pm \\
0.16 \mathrm{a}\end{array}$ & $\begin{array}{c}36.02 \pm \\
1.06 \mathrm{a}\end{array}$ & $\begin{array}{c}481.30 \pm \\
17.02 \mathrm{a}\end{array}$ & $\begin{array}{c}11.45 \pm \\
0.55 \mathrm{~b}\end{array}$ & $\begin{array}{c}42.05 \pm \\
1.54 \mathrm{~b}\end{array}$ & $\begin{array}{c}421.83 \pm \\
13.37 \mathrm{~b}\end{array}$ & $\begin{array}{c}12.21 \pm \\
0.66 \mathrm{c}\end{array}$ & $\begin{array}{c}34.59 \pm \\
1.04 \mathrm{a}\end{array}$ \\
\hline
\end{tabular}

The data are presented as mean \pm standard deviation $(n=3)$. Different lowercase letters represent significant differences among differentaged stands under the same month.

Table A2. Univariate models of the soil respiration rate against the litter input one month ago in different-aged Betula platuphylla forests of permafrost region, Northeast China at the monthly scale.

\begin{tabular}{cccc}
\hline & Regression Equation & $\mathbf{R}^{\mathbf{2}}$ & $p$ \\
\hline $25 \mathrm{a}$ & $\mathrm{Rs}=3.889 \mathrm{e}^{-0.995 \mathrm{~L}}$ & 0.613 & 0.007 \\
$40 \mathrm{a}$ & $\mathrm{Rs}=8.341 \mathrm{e}^{-1.112 \mathrm{~L}}$ & 0.653 & 0.005 \\
$61 \mathrm{a}$ & $\mathrm{Rs}=6.544 \mathrm{e}^{-0.878 \mathrm{~L}}$ & 0.665 & 0.004 \\
\hline
\end{tabular}

\section{References}

1. Wang, Y.; Li, X.Y.; Wu, X.C.; Wu, H.W.; Zhang, J.H.; Wu, Y.N.; Zhao, C.Y. Temporal changes of soil respiration in a subalpine meadow in the Heihe River Basin, Northwest China. Catena 2019, 178, 267-275. [CrossRef]

2. Yan, G.; Xing, Y.; Wang, Q.; Mu, C. Short Legacy Effects of Growing Season Nitrogen Addition and Reduced Precipitation alter Soil Respiration during Nongrowing Season. Forests 2020, 11, 358. [CrossRef]

3. Janssens, I.A.; Dore, S.; Epron, D.; Lankreijer, H.; Buchmann, N.; Longdoz, B.; Brossaud, J.; Montagnani, L. Climatic Influences on Seasonal and Spatial Differences in Soil $\mathrm{CO}_{2}$ Efflux; Springer: Berlin/Heidelberg, Germany, 2003; pp. 233-253.

4. Zimmermann, M.; Meir, P.; Bird, M.; Malhi, Y.; Ccahuana, A. Litter contribution to diurnal and annual soil respiration in a tropical montane cloud forest. Soil Biol. Biochem. 2009, 41, 1338-1340. [CrossRef]

5. Valentini, C.M.A.; Sanches, L.; de Paula, S.R.; Vourlitis, G.L.; de Souza Nogueira, J.; Pinto, O.B., Jr.; de Almeida Lobo, F. Soil respiration and aboveground litter dynamics of a tropical transitional forest in northwest Mato Grosso, Brazil. J. Geophys. Res. Biogeosci. 2008, 113. [CrossRef]

6. Han, C.X.; Liu, T.X.; Lu, X.X.; Duan, L.M.; Singh, V.P.; Ma, L.Q. Effect of litter on soil respiration in a man-made Populus L. forest in a dune-meadow transitional region in China's Horqin sandy land. Ecol. Eng. 2019, 127, 276-284. [CrossRef]

7. Shilong, P.; Philippe, C.; Pierre, F.; Philippe, P.; Markus, R.; Sebastiaan, L.; Hank, M.; Jingyun, F.; Alan, B.; Anping, C. Net carbon dioxide losses of northern ecosystems in response to autumn warming. Nature 2008, 451, 49-52.

8. Peng, S.; Piao, S.; Tao, W.; Sun, J.; Shen, Z. Temperature sensitivity of soil respiration in different ecosystems in China. Soil Biol. Biochem. 2009, 41, 1008-1014. [CrossRef]

9. Yan, J.; Zhang, X.; Liu, J.; Li, H.; Ding, G. MODIS-Derived Estimation of Soil Respiration within Five Cold Temperate Coniferous Forest Sites in the Eastern Loess Plateau, China. Forests 2020, 11, 131. [CrossRef]

10. Tarnocai, C.; Canadell, J.G.; Schuur, E.A.G.; Kuhry, P.; Mazhitova, G.; Zimov, S. Soil organic carbon pools in the northern circumpolar permafrost region. Glob. Biogeochem. Cycles 2009, 23. [CrossRef]

11. Jobbágy, E.G.; Jackson, R.B. The vertical distribution of soil organic carbon and its relation to climate and vegetation. Ecol. Appl. 2000, 10, 423-436. [CrossRef]

12. Du, E.Z.; Zhou, Z.; Li, P.; Jiang, L.; Hu, X.Y.; Fang, J.Y. Winter soil respiration during soil-freezing process in a boreal forest in Northeast China. J. Plant Ecol. 2013, 6, 349-357. [CrossRef] 
13. Wang, J.J.; Lai, L.M.; Zhao, X.C.; Jiang, L.H.; Wang, Y.J.; Zhou, J.H.; Wang, F.; Zhang, C.; Zheng, Y.R. Litter priming and trenching greatly affect soil respiration in a mature subtropical evergreen broadleaf forest in Southwestern China. Contemp. Probl. Ecol. 2015, 8, 486-494. [CrossRef]

14. Crow, S.E.; Lajtha, K.; Bowden, R.D.; Yano, Y.; Brant, J.B.; Caldwell, B.A.; Sulzman, E.W. Increased coniferous needle inputs accelerate decomposition of soil carbon in an old-growth forest. For. Ecol. Manag. 2009, 258, 2224-2232. [CrossRef]

15. Hickler, T.; Smith, B.; Prentice, I.C.; Mjöfors, K.; Sykes, M.T. $\mathrm{CO}_{2}$ fertilization in temperate FACE experiments not representative of boreal and tropical forests. Glob. Chang. Biol. 2008, 14, 1531-1542. [CrossRef]

16. Wang, Y.D.; Wang, H.M.; Ma, Z.Q.; Wen, X.F.; Li, Q.K.; Liu, Y.F.; Sun, X.M.; Yu, G.R. Contribution of Aboveground Litter Decomposition to Soil Respiration in a Subtropical Coniferous Plantation in Southern China. Asia-Pac. J. Atmos. Sci. 2009, 45, 137-147.

17. Brechet, L.; Le Dantec, V.; Ponton, S.; Goret, J.Y.; Sayer, E.; Bonal, D.; Freycon, V.; Roy, J.; Epron, D. Short- and Long-term Influence of Litter Quality and Quantity on Simulated Heterotrophic Soil Respiration in a Lowland Tropical Forest. Ecosystems 2017, 20, 1190-1204. [CrossRef]

18. Liu, X.F.; Lin, T.C.; Yang, Z.J.; Vadeboncoeur, M.A.; Lin, C.F.; Xiong, D.C.; Lin, W.S.; Chen, G.S.; Xie, J.S.; Li, Y.Q.; et al. Increased litter in subtropical forests boosts soil respiration in natural forests but not plantations of Castanopsis carlesii. Plant Soil 2017, 418, 141-151. [CrossRef]

19. Chen, X.L.; Chen, H.Y.H. Global effects of plant litter alterations on soil $\mathrm{CO}_{2}$ to the atmosphere. Glob. Chang. Biol. 2018, 24, 3462-3471. [CrossRef]

20. Xu, S.; Liu, L.L.; Sayer, E.J. Variability of above-ground litter inputs alters soil physicochemical and biological processes: A meta-analysis of litterfall-manipulation experiments. Biogeosciences 2013, 10, 7423-7433. [CrossRef]

21. Yu, K.; Yao, X.; Deng, Y.; Lai, Z.; Lin, L.; Liu, J. Effects of stand age on soil respiration in Pinus massoniana plantations in the hilly red soil region of Southern China. Catena 2019, 178, 313-321. [CrossRef]

22. Kukumagi, M.; Ostonen, I.; Uri, V.; Helmisaari, H.-S.; Kanal, A.; Kull, O.; Lohmus, K. Variation of soil respiration and its components in hemiboreal Norway spruce stands of different ages. Plant Soil 2017, 414, 265-280. [CrossRef]

23. Trap, J.; Hättenschwiler, S.; Gattin, I.; Aubert, M. Forest ageing: An unexpected driver of beech leaf litter quality variability in European forests with strong consequences on soil processes. For. Ecol. Manag. 2013, 302, 338-345. [CrossRef]

24. Ma, Y.; Piao, S.; Sun, Z.; Lin, X.; Wang, T.; Yue, C.; Yang, Y. Stand ages regulate the response of soil respiration to temperature in a Larix principis-rupprechtii plantation. Agric. For. Meteorol. 2014, 184, 179-187. [CrossRef]

25. Saiz, G.; Byrne, K.A.; Butterbach-Bahl, K.; Kiese, R.; Blujdeas, V.; Farrell, E.P. Stand age-related effects on soil respiration in a first rotation Sitka spruce chronosequence in central Ireland. Glob. Chang. Biol. 2006, 12, 1007-1020. [CrossRef]

26. Klopatek, J.M. Belowground carbon pools and processes in different age stands of Douglas-fir. Tree Physiol. 2002, 22, 197-204. [CrossRef]

27. Bronson, D.R.; Gower, S.T.; Tanner, M.; Linder, S.; Herk, I.V. Response of soil surface $\mathrm{CO}_{2}$ flux in a boreal forest to ecosystem warming. Glob. Chang. Biol. 2008, 14, 856-867. [CrossRef]

28. Khomik, M.; Arain, M.A.; McCaughey, J.H. Temporal and spatial variability of soil respiration in a boreal mixedwood forest. Agric. For. Meteorol. 2006, 140, 244-256. [CrossRef]

29. Wang, C.; Bond-Lamberty, B.; Gower, S.T. Soil surface $\mathrm{CO}_{2}$ flux in a boreal black spruce fire chronosequence. J. Geophys. Res. Atmos. 2002, 107, 8224-8231. [CrossRef]

30. Sun, J.; Li, X.-Z.; Wang, X.-W.; Lv, J.-J.; Li, Z.-M.; Hu, Y.-M. Latitudinal changes in species diversity of permafrost wetland plant communities in Great Xing'an Mountain valleys of Northeast China. Acta Ecol. Sin. 2009, 29, 272-277. [CrossRef]

31. Duan, L.L.; Man, X.L.; Kurylyk, B.L.; Cai, T.J. Increasing Winter Baseflow in Response to Permafrost Thaw and Precipitation Regime Shifts in Northeastern China. Water 2017, 9, 25. [CrossRef]

32. Wu, X.W.; Zang, S.Y.; Ma, D.L.; Ren, J.H.; Chen, Q.; Dong, X.F. Emissions of $\mathrm{CO}_{2}, \mathrm{CH}_{4}$, and $\mathrm{N}_{2} \mathrm{O}$ Fluxes from Forest Soil in Permafrost Region of Daxing'an Mountains, Northeast China. Int. J. Environ. Res. Public Health 2019, 16, 2999. [CrossRef] [PubMed]

33. Tian, X.; Shu, L.; Wang, M.; Zhao, F.; Chen, L. The fire Danger and Fire Regime for the Daxing'anling Region for 1987-2010. Procedia Eng. 2013, 62, 1023-1031. [CrossRef]

34. Zhang, L.; Dong, L.; Liu, Q.; Liu, Z. Spatial Patterns and Interspecific Associations During Natural Regeneration in Three Types of Secondary Forest in the Central Part of the Greater Khingan Mountains, Heilongjiang Province, China. Forests 2020, 11, 152. [CrossRef]

35. Wei, H.; Man, X. Carbon storage and its allocation in Betula platyphylla forests of different ages in cold temperate zone of China. Chin. J. Plant Ecol. 2019, 43, 843-852. [CrossRef]

36. Yu, Z.; Sun, G.; Cai, T.; Hallema, D.; Duan, L. Water Yield Responses to Gradual Changes in Forest Structure and Species Composition in a Subboreal Watershed in Northeastern China. Forests 2019, 10, 211. [CrossRef]

37. Sun, T.; Dong, L.; Mao, Z.; Li, Y. Fine root dynamics of trees and understorey vegetation in a chronosequence of Betula platyphylla stands. For. Ecol. Manag. 2015, 346, 1-9. [CrossRef]

38. Duan, B.; Man, X.; Cai, T.; Xiao, R.; Ge, Z. Increasing soil organic carbon and nitrogen stocks along with secondary forest succession in permafrost region of the Daxing'an Mountains, Northeast China. Glob. Ecol. Conserv. 2020, e01258. [CrossRef]

39. Duan, L.L.; Man, X.L.; Kurylyk, B.L.; Cai, T.J.; Li, Q. Distinguishing streamflow trends caused by changes in climate, forest cover, and permafrost in a large watershed in northeastern China. Hydrol. Process. 2017, 31, 1938-1951. [CrossRef] 
40. Gao, W.; Zhao, W.; Yang, H.; Yang, H.; Chen, G.; Luo, Y.; Fang, H.; Li, S. Effects of nitrogen addition on soil inorganic N content and soil $\mathrm{N}$ mineralization of a cold-temperate coniferous forest in Great Xing'an Mountains. Acta Ecol. Sin. 2015, 35, 130-136. [CrossRef]

41. Xiao, R.; Man, X.; Duan, B. Carbon and Nitrogen Stocks in Three Types of Larix gmelinii Forests in Daxing'an Mountains, Northeast China. Forests 2020, 11, 305. [CrossRef]

42. Yang, Y.; Luo, Y. Carbon: Nitrogen stoichiometry in forest ecosystems during stand development. Glob. Ecol. Biogeogr. 2011, 20, 354-361. [CrossRef]

43. Zhang, X.; Li, Y.; Ning, C.; Zheng, W.; Zhao, D.; Li, Z.; Yan, W. Litter Management as a Key Factor Relieves Soil Respiration Decay in an Urban-Adjacent Camphor Forest under a Short-Term Nitrogen Increment. Forests 2020, 11, 216. [CrossRef]

44. Zhang, H.; Qian, Z.; Zhuang, S. Effects of Soil Temperature, Water Content, Species, and Fertilization on Soil Respiration in Bamboo Forest in Subtropical China. Forests 2020, 11, 99. [CrossRef]

45. Boone, R.D.; Nadelhoffer, K.J.; Canary, J.D.; Kaye, J.P. Roots exert a strong influence on the temperature sensitivity of soil respiration. Nature 1998, 396, 570-572. [CrossRef]

46. DeForest, J.L.; Chen, J.Q.; McNulty, S.G. Leaf litter is an important mediator of soil respiration in an oak-dominated forest. Int. J. Biometeorol. 2009, 53, 127-134. [CrossRef] [PubMed]

47. Zhao, X.; Li, F.D.; Zhang, W.J.; Ai, Z.P. Contribution of aboveground litter to soil respiration in Populus davidiana Dode plantations at different stand ages. J. Mt. Sci. 2016, 13, 1000-1012. [CrossRef]

48. Han, T.F.; Huang, W.J.; Liu, J.X.; Zhou, G.Y.; Xiao, Y. Different soil respiration responses to litter manipulation in three subtropical successional forests. Sci. Rep. 2015, 5, 8-15. [CrossRef]

49. Yi, Z.; Fu, S.; Yi, W.; Zhou, G.; Mo, J.; Zhang, D.; Ding, M.; Wang, X.; Zhou, L. Partitioning soil respiration of subtropical forests with different successional stages in south China. For. Ecol. Manag. 2007, 243, 178-186. [CrossRef]

50. Leff, J.W.; William, R.W.; Philip, G.T.; Alan, R.T.; Diana, R.N.; Grandy, A.S.; Cory, C.C. Experimental litterfall manipulation drives large and rapid changes in soil carbon cycling in a wet tropical forest. Glob. Chang. Biol. 2012, 18, 2969-2979. [CrossRef]

51. Xiao, W.; Ge, X.; Zeng, L.; Huang, Z.; Lei, J.; Zhou, B.; Li, M. Rates of Litter Decomposition and Soil Respiration in Relation to Soil Temperature and Water in Different-Aged Pinus massoniana Forests in the Three Gorges Reservoir Area, China. PLoS ONE 2014, 9, e101890. [CrossRef]

52. Huang, W.; Spohn, M. Effects of long-term litter manipulation on soil carbon, nitrogen, and phosphorus in a temperate deciduous forest. Soil Biol. Biochem. 2015, 83, 12-18. [CrossRef]

53. Gough, C.M.; Seiler, J.R.; Wiseman, P.E.; Maier, C.A. Soil $\mathrm{CO}_{2}$ efflux in loblolly pine (Pinus taeda L.) plantations on the Virginia Piedmont and South Carolina Coastal Plain over a rotation-length chronosequence. Biogeochemistry (Dordrecht) 2005, 73, 127-147. [CrossRef] 